\author{
Павлов О.І. \\ доктор економічних наук, професор, \\ завідувач кафедри економіки промисловості, \\ Одеська національна академія харчових технологій \\ вул. Канатна, 112, м. Одеса, Україна, 65039 \\ E-mail: pavlovodessa@mail.ru \\ Лисюк В.M. \\ доктор економічних наук, професор, \\ завідувач відділу ринкових механізмів та структур \\ E-mail: vlisyuk@ukr.net \\ Деркач T.B. \\ кандидат географрічних наук, докторант \\ відділ ринкових механізмів та структур \\ Інститут проблем ринку та економіко-екологічних досліджень НАН України \\ Французький бульвар, 29, м. Одеса, Україна, 65044 \\ E-mail: igd62@mail.ru
}

\title{
ДЕРЖАВНЕ РЕГУЛЮВАННЯ ІНТЕГРАЦІЙНИХ ПРОЦЕСІВ НА СТРАТЕГІЧНИХ АГРОПРОДОВОЛЬЧИХ РИНКАХ
}

Визначено природу економічної інтеграції, виділено дві її фрорми (активна та пасивна), доведено домінування пасивної інтеграційної політики в аграрному секторі України. Обґрунтовано рушійні сили інтеграційних процесів на стратегічних ринках зерна та молочної продукції. Визначено пріоритетні напрями державного регулювання інтеграційних процесів на вітчизняних агропродовольчих ринках.

Ключові слова: інтеграційні процеси, інтеграційна політика, агропродовольчі ринки, відтворювальні процеси, державне регулювання.

Постановка проблеми та ї̈ зв'язок з важливими науковими та практичними завданнями. Аналіз інтеграційних систем у світовому господарстві свідчить про високу складність і різноманітність форм їх прояву в залежності від методів державного регулювання, ступеня реалізації економічних інтересів держави або ринкових суб'єктів, структури агропродовольчої сфери та інших чинників. Необхідність державного регулювання інтеграційних процесів (далі - ІП) стратегічних агропродовольчих ринків пов'язана 3 потребами забезпечення продовольчої безпеки на всіх рівнях, стимулювання розвитку інтеграційних структур у контексті підвищення ефективності функціонування товарних ринків, участі держави в агропромислових об'єднаннях, відновлення керованості в агропродовольчій сфері та впливу на нього державних органів влади.

Аналіз останніх публікацій 3 проблеми. Питання ефективності застосування механізмів державного регулювання ІП в агропродовольчій сфері розглядаються такими вітчизняними вченими, як В. Афанасьєв, А. Базиков, А. Гуторов, В. Залізко, I. Іртищева, М. Лещева, Г. Мостовий, Т. Осташко, Б. Пасхавер, М. Поляруш, В. Шебанін та ін. Водночас недостатньо дослідженими залишаються питання обгрунтування механізмів регулювання ІП на стратегічних агропродовольчих ринках 3 урахуванням особливостей взаємодій між суб'єктами їх структуроутворюючих секторів.
Формулювання цілей дослідження. Мета статті - обгрунтування напрямів і механізмів державного регулювання інтеграційних процесів на стратегічних агропродовольчих ринках. Для іiі реалізації сформульовано такі завдання:

- визначення природи дефініції «економічна інтеграція»;

- аналіз передумов і деформацій ІП в аграрній сфері України;

- секторний аналіз рушійних сил ІП на стратегічних ринках зерна та молочної продукції;

- обгрунтування пріоритетних напрямів державної інтеграційної політики на національних агропродовольчих ринках в умовах глобалізації.

Виклад основних результатів та їх обгрунтування. Вихідним пунктом дослідження є визначення природи дефініції «інтеграція». С. В. Мочерний трактує інтеграцію (лат. integratio - відновлення і цілий) як поступове зближення та об'єднання економічних суб' єктів у процесів їх взаємодії (взаємовпливу, взаємопроникнення, взаємозбагачення тощо) [1, c. 668]. Економічна інтеграція - це рух економічної системи, тобто зміна іiі стану як по відношенню до інших систем, так і по відношенню до ії попереднього стану. Проведений авторами аналіз різноманітних визначень інтеграції дозволив виділити іiі головні характеристики [2, с. 196]:

- це процес - економічний процес; 
- даний процес спрямований на економічний розвиток держави;

- рушійною силою ІП є механізми рухомості товарів і капіталів між учасниками (суб' єктами) інтеграції;

- інтеграція на практиці реалізується через торгівлю товарами (послугами) та активами суб'єктів, у т.ч. фінансовими.

В залежності від ступеня реалізації державних економічних інтересів авторами виділено дві форми інтеграції (інтеграційної політики): активну та пасивну. Пасивна інтеграційна політика ставить за мету й реалізує інтереси: (а) інших держав або інтеграційних об'єднань; (б) вузького кола представників держави (олігархів, правлячої партії, осіб); (в) тільки політичних угрупувань, а також реалізується під зовнішнім тиском найсильніших суб' єктів, інтеграційних структур, інтереси яких не пов'язані з економічними інтересами держави. За пасивної форми метою інтеграції виступає не економічне зростання держави, а сам інтеграційний процес як самоціль. Активна інтеграційна політика впроваджується під впливом виваженої державної соціально-економічної політики, в якій інтеграція виконує не головну, а допоміжну роль, а саме: підсилює механізми активізації товарнофінансового обігу з метою залучення капіталу в національну економіку, розвитку іiі ринків, передусім реального сектору, підвищення рівня життя і добробуту населення [2, с. 199].

У більшості країн з ринковою економікою створено дієві системи державного регулювання агропромислової інтеграції, які реалізують такі завдання [3, с. 188]:

- підтримка продовольчої безпеки;

- підтримка стабільної економічної ситуації в сільському господарстві;

- стабілізація ринкової кон'юнктури і мінімізація коливань прибутковості в аграрному сектоpi;

- запобігання небажаним міграційним процесам;

- підтримка фінансування програм;

- допомога товаровиробникам в адаптації до нових умов;

- захист внутрішнього ринку;

- забезпечення конкурентоспроможності участі національних товаровиробників в міжнародному розподілі праці тощо.

При цьому державами застосовується гарантована закупівля надлишків продукції за заниженими цінами, закупівельні й товарні інтервенції на ринку продовольства, специфічні форми пільгового кредитування, митне регулювання (як економічне, так i адміністративне) тощо [4, с. 117]. Використання перелічених регуляторних механізмів забезпечує реалізацію економічних інтересів держави на стратегічних агропродовольчих ринках, що $є$ свідченням впровадження активної інтеграційної політики.

В Україні домінує пасивна форма ІП в агропродовольчій сфері, характерними ознаками якої
$€$ нерегульованість державою аграрних перетворень, стихійність процесу, реалізація економічних інтересів найсильніших суб'єктів господарювання, наділених ринковою владою. Відсутність державної політики підтримки розвитку сільськогосподарської кооперації обумовило домінування в аграрному секторі агрохолдингів, які на засадах оренди концентрують земельні ресурси, створюють складські та інші потужності. При цьому на досягнення поставленої мети корпоративних структур націлюється система державного регулювання аграрного сектору та механізми його бюджетної підтримки.

Згідно аналітичним даним [5, с. 74], в Україні 10 найбільших агрохолдингів обробляє близько 3 млн. га сільськогосподарських угідь. Щорічно тенденція укрупнення агрохолдингів зростає. В 2011 р. корпорація «Укрлендфармінг» шляхом поглинання агрохолдингів «Авангард», «Райз», «ДакорАгроХолдинг» і «Робуста-Агро-Інвест» сформувала найбільший земельний банк у Європі - 532 тис. га. Для порівняння: середній розмір американської ферми становить 175 га, а найбільші господарства обробляють 1,0-1,5 тис. га; у Франції ці показники становлять відповідно 50 і 200 га [6]. Агрохолдинги користуються державною підтримкою. Так, у 2009-2010 рр. ПАТ «Миронівський хлібопродукт» і «Мрія» отримали державну підтримку в обсязі 2,198 млрд. грн., при цьому їх чистий дохід перевищив 6 млрд. грн. [5, c. 76].

Проникаючи у найвигідніші галузі сільського господарства, агрохолдинги забезпечують собі конкурентні переваги шляхом глибокої спеціалізації, високої концентрації та індустріалізації окремих виробництв, застосування великих доз мінеральних добрив i хімічних засобів захисту, генетично модифікованих організмів. Позитивні аспекти цих процесів для великого бізнесу супроводжуються негативними структурними змінами в агропродовольчому секторі, руйнуванням збалансованих місцевих аграрних комплексів, зумовленим витісненням 3 виробництва не вигідних для великого бізнесу видів сільськогосподарської продукції. Це, у свою чергу, породжує підвищення продовольчої залежності національного ринку від імпорту цілого ряду важливих для людей видів продовольства, зменшення зайнятості сільського населення, витіснення його в особисті селянські господарства і за межі сіл. Прагнення агробізнесу до збільшення виробництва валютоокупної продукції вступило в суперечність із вимогами закону плодозміни, намітилося перенасичення сівозмін одними й тими ж культурами, порушення співвідношення між рослинництвом і тваринництвом, між орними землями і пасовищами, у результаті дедалі частіше почали виявлятися біологічна перевтома грунтів і значне погіршення їх родючості [6].

Таким чином, реалізація економічних інтересів агрохолдингів супроводжується знищенням соціальних i екологічних функцій сільського господарства. В Україні не реалізується концепція багатофункціональності сільського господарства, на якій базується світова аграрна політика. Подолання 
негативних наслідків агрохолдинізації обумовлює необхідність розробки та впровадження активної інтеграційної політики, сфокусованої на реалізації економічних інтересів держави, а не корпоративних структур, наділених ринковою владою. Методологічним підгрунтям обгрунтування іiі пріоритетів може стати аналіз відтворювальних процесів у секторах стратегічних агропродовольчих ринків (сировинному, виробничому, інфраструктурному та споживчому), який дозволяє ідентифікувати секторні диспропорції розвитку та взаємозв'язки між суміжними суб'єктами, як рушійні сили інтеграції. Авторську методологію секторного аналізу [7, с. 144-159] використаємо для обгрунтування пріоритетних напрямів державного регулювання ІП на стратегічних національних ринках молочної та зернопереробної продукції.

Проведений аналіз структури виробництва молока в суб'єктному розрізі засвідчив зростання частки господарств населення з 23,97 \% в 1990 р. до $77,52 \%$ в 2013 р. (табл. 1). Серед підприємств, що виробляють молочну сировину, переважає дрібнотоварність (у близько половини загальна кількість корів не перевищує 100 голів). Починаючи з 2011 р. намітилася тенденція до незначного зростання частки сільськогосподарських підприємств у виробництві молока (з 20,26 \% в 2011 р. до $22,48 \%$ у 2013 р.).

\section{Динаміка та структура виробництва (суб'сктний розріз) в сировинному секторі ринків молочної та зернопереробної продукції*}

\begin{tabular}{|c|c|c|c|c|c|c|c|c|c|c|}
\hline \multirow{2}{*}{ Категорії господарств } & \multicolumn{10}{|c|}{ Роки } \\
\hline & 1990 & 1995 & 2000 & 2005 & 2008 & 2009 & 2010 & 2011 & 2012 & 2013 \\
\hline $\begin{array}{l}\text { 1. Виробництво молока, } \\
\text { млн. тонн }\end{array}$ & 24,51 & 17,27 & 12,66 & 13,71 & 11,76 & 11,61 & 11,25 & 11,09 & 11,38 & 11,49 \\
\hline $\begin{array}{l}\text { 2. Структура виробнищтва } \\
\text { молока, \%: } \\
\text { 2.1. Сільськогосподарські } \\
\text { підприємства }\end{array}$ & 76,03 & 54,67 & 28,99 & 18,83 & 17,77 & 19,26 & 19,71 & 20,26 & 22,28 & 22,48 \\
\hline $\begin{array}{l}\text { у т.ч. фермерські госпо- } \\
\text { дарства }\end{array}$ & 0,00 & 0,24 & 0,54 & 0,70 & 0,82 & 0,91 & 1,00 & 1,11 & 1,27 & 1,37 \\
\hline 2.2. Господарства населення & 23,97 & 45,33 & 71,01 & 81,17 & 82,23 & 80,74 & 80,29 & 79,74 & 77,72 & 77,52 \\
\hline $\begin{array}{l}\text { 3. Виробництво зернових } \\
\text { культур, млн. тонн }\end{array}$ & 51,01 & 33,93 & 24,46 & 38,02 & 53,29 & 46,03 & 39,27 & 56,75 & 46,22 & 63,05 \\
\hline $\begin{array}{l}\text { 4. Структура зернового ви- } \\
\text { робниитва, \%: } \\
\text { 4.1. Сільськогосподарські } \\
\text { підприємства }\end{array}$ & 97,17 & 91,90 & 81,62 & 75,73 & 78,99 & 77,87 & 75,83 & 77,92 & 78,06 & 78,76 \\
\hline $\begin{array}{l}\text { у т.ч. фермерські госпо- } \\
\text { дарства }\end{array}$ & 0,00 & 1,50 & 5,14 & 10,74 & 12,87 & 12,07 & 11,98 & 11,87 & 10,92 & 11,93 \\
\hline 4.2. Господарства населення & 2,83 & 8,10 & 18,38 & 24,27 & 21,01 & 22,13 & 24,17 & 22,08 & 21,94 & 21,24 \\
\hline
\end{tabular}

*Складено за даними Державної служби статистики України [9].

Проведений секторний аналіз відтворювальних процесів на вітчизняному ринку молочної продукції [10;11] довів, що основними рушійними силами поглиблення взаємовідносин на основі інтеграції є проблеми забезпечення сировиною молокопереробних підприємств. Проблеми сировинного сектору позначились на розвитку виробничого та споживчого секторів, обумовивши нерівновагу системи, а саме: зменшення поголів'я корів (в 2013 р. на 70,1 \% і 49,4 \% порівняно з 1990 р. і 2000 р.) призвело до скорочення обсягів виробництва молока (на 53,1 і 9,2\% відповідно - див. табл. 1) та рівня його товарності (близько $41 \%$ ); дрібнотоварне виробництво зумовило низьку якість сировини, яка, в свою чергу, спричинила невідповідність продукції молокопереробки міжнародним нормам якості; низька ціна на молочну продукцію та їі диспаритет по відношенню до готової продукції зумовили низьку рентабельність виробниц- тва молока, яка впродовж 2000-2006 рр. здебільшого мала від'ємне значення; крім того, висока ціна на продукцію для кінцевих споживачів у поєднанні 3 тенденцією скорочення випуску більшості молочних продуктів спричинили невідповідність попиту раціональним нормам споживання [10].

Дефіцит сировини молокопереробні підприємства були змушені компенсувати імпортом товару та вдаватись до фальсифікації товару, штучно замінюючи молочні жири на рослинні. Оцінка впливу зміни рівня товарності молока в господарствах населення на перспективні показники забезпечення продовольчої безпеки в молочній галузі довела, що для молокопереробних підприємств $є$ доцільним сприяти кооперуванню дрібнотоварних постачальників сировини [11]. Саме даний напрям IП є пріоритетним. 
На противагу молочному ринку, в сировинному секторі ринку зернопродуктів головними виробниками зернових культур $є$ сільськогосподарські підприємства (78,76 \% у 2013 р.). Водночас характерною $є$ тенденція до зростання частки господарств населення - $32,83 \%$ в 1990 р. до 21,24 \% в 2013 р. (див. табл. 1). Особливостями структури зерновиробників $\epsilon$, по-перше, значна роль господарств населення та фермерських господарств у забезпеченні продовольчої безпеки держави, по-друге, зростання масштабів вертикальної інтеграції. Агрохолдинги віддають перевагу виробництву високорентабельних культур, орієнтованих на експорт (передусім кукурудзи), водночас господарства населення вирощують пріоритетну для національного зернопродуктового комплексу малорентабельну культуру - пшеницю, не отримуючи при цьому жодного виду державної підтримки [12, c. $148-150]$.

Проведений секторний аналіз відтворювальних процесів на зерновому ринку України [13] довів, що ІП здійснюються в сфері первинної переробки зерна за напрямами технологічного ланцюга «виробництво - зберігання - експорт» або «зберігання експорт» та відображають економічні інтереси трейдерів як розпорядників $86,8 \%$ зерна, реалізованих агропідприємствами. Наслідками пасивної інтеграційної політики на зерновому ринку є незбалансованість економічних відносин між суб'єктами аграрного і переробного секторів; зростання обсягів позаелеваторного зберігання зерна; зменшення виробництва високоякісного продовольчого зерна; моновиробництво експортоорієнтованих культур; низький рівень завантаження потужностей зернопереробних підприємств (близько $30 \%$ ); скорочення виробництва борошна і комбікормів (на $70 \%$ і $58 \%$ в 2013 р. порівняно з 1990 р.) за одночасного зростання валового зернового збору (на $24 \%$ ); зменшення виробництва пшениці і зернобобових культур (на 27 і 89 \%) для внутрішньої переробки. Такі зміни є свідченням неефективного використання виробничих потенціалів ринків продуктів зернопереробки, зменшення обсягів продукування доданої вартості та податкових надходжень у їх ресурсоутворювальних виробничих секторах, що не відповідає інтересам держави та суспільства та обумовлює необхідність переорієнтації інтеграційних стратегій зі сфери первинної на сферу вторинної переробки зерна [12, c. 299].

Головна мета створення сучасних інтеграційних систем полягає не тільки у встановленні прямих зв'язків між учасниками, скороченні витрат та збільшенні прибутку, а й у подоланні диспаритету цін, забезпечення пропорційного розподілу доходів між секторами агропродовольчих ринків, відтворювального рівня цін у базових їх секторах, зокрема, сировинному. Проведений аналіз (табл. 2) свідчить про варіативність і низький рівень рентабельності аграрної продукції (в 2013 р. 1,5 \% для зерна і 13,1 \% для молока), який не спроможний забезпечити розширене відтворення матеріальних, фінансових і трудових ресурсів у сировинному секторі ринків. У 2008-2009 pp., 2012-2013 pр. темп приросту собівартості зерна випереджав темп приросту середніх цін; для молока вказана тенденція мала місце в 2008, 2009, 2012 роках. Слід відзначити, що в періоди різкого падіння рентабельності зерна доходність молока збільшується (2013 р.), і навпаки (2012 р.), що свідчить про значний вплив цінової кон'юнктури зернового ринку на вартість молока, у структурі собівартості якого частка кормів досягає 72,7\% (у 2008 р. $71 \%)$.

Таблиця 2

Динаміка цін, собівартості та рентабельності товарної продукції сільськогосподарських підприсмств України"

\begin{tabular}{|c|c|c|c|c|c|c|c|}
\hline \multirow{2}{*}{ Показники } & \multicolumn{7}{|c|}{ Роки } \\
\hline & 2007 & 2008 & 2009 & 2010 & 2011 & 2012 & 2013 \\
\hline \multicolumn{8}{|c|}{ Зернові та зернобобові культури } \\
\hline 1. Собівартість реалізації 1 т & 649,3 & 669,9 & 753,0 & 988,0 & 1081,8 & 1346,1 & 1258,3 \\
\hline у\% до попереднього року & 134,0 & 103,2 & 112,4 & 131,2 & 109,5 & 124,4 & 93,5 \\
\hline 2. Середня ціна реалізації 1 т & 835,3 & 779,6 & 807,6 & 1125 & 1363,6 & 1551 & 1288,6 \\
\hline у\% до попереднього року & 160,6 & 93,3 & 103,6 & 139,3 & 121,2 & 113,7 & 83,1 \\
\hline 3. Прибуток від реалізації 1 т & 186,0 & 109,6 & 54,6 & 137,0 & 281,8 & 204,9 & 30,3 \\
\hline у\% до попереднього року & $5,2 p$. & 59,0 & 49,8 & 250,9 & 205,7 & 72,7 & 14,8 \\
\hline 4. Рентабельність продукції, \% & 28,7 & 16,4 & 7,3 & 13,9 & 26,1 & 15,2 & 1,5 \\
\hline \multicolumn{8}{|c|}{ Молоко } \\
\hline 1. Собівартість реалізації 1 т & 1276 & 1697,8 & 1735,5 & 2289,4 & 2643 & 2665,2 & 3025,7 \\
\hline у\% до попереднього року & 128,3 & 133,1 & 102,2 & 131,9 & 115,4 & 100,8 & 113,5 \\
\hline 2. Середня ціна реалізації 1 т & 1452,5 & 1768,0 & 1760,3 & 2698,1 & 3131,2 & 2727,4 & 3405,5 \\
\hline у\% до попереднього року & 151,6 & 121,7 & 99,6 & 153,3 & 116,1 & 87,1 & 124,9 \\
\hline 3. Прибуток від реалізації 1 т & 176,5 & 70,2 & 24,8 & 408,7 & 488,2 & 62,2 & 379,8 \\
\hline
\end{tabular}




\begin{tabular}{|l|c|c|c|c|c|c|c|}
\hline$y \%$ до попереднього року & 109,1 & 39,8 & 35,3 & 16,5 p. & 119,5 & 12,7 & $6,1 \mathrm{p}$. \\
\hline 4. Рентабельність продукції, \% & 13,8 & 4,1 & 1,4 & 17,9 & 18,5 & 2,3 & 13,1 \\
\hline
\end{tabular}

*Складено за даними Державної служби статистики України [9].

Проявом непропорційності міжсекторного розподілу доходів є невідповідність рентабельності продукції (послуг) рівню новоствореної в певному секторі інтегрованого ринку доданої вартості. Так, на зерновому ринку найвищий рівень доходності притаманний інфраструктурному сектору (близько $35 \%$ ), частка доданої вартості якого в ціні товару не перевищує $5 \%$, найнижчий - аграрному сектору (1,5\%), частка доданої вартості якого в ціні зерна є найбільшою серед секторів і складає 30 \% [12, с. 222]. Невирішеність багаторівневого завдання ефективного функціонування агропродовольчих ринків, насамперед, збалансування товарно-фінансових потоків між секторами ринків, забезпечення міжсекторної пропорційності розподілу доходів, відтворювального рівня цін у сировинному секторі, досягнення паритетності цін між аграрною та промисловою продукцію, обумовлює необхідність державного регулювання IП на стратегічних ринках України.

На думку авторів, державне регулювання інтеграційних проиесів - це взаємоузгоджений комплекс заходів, здійснюваних державою для забезпечення ефективності функціонування агропродовольчих ринків, досягнення стійких економічних, виробничих і технологічних зв'язків між суб'єктами i секторами даних ринків, найповнішої реалізації їх відтворювальних функцій у системі національної економіки. Кінцевою метою державного регулювання IП є забезпечення розширеного відтворення матеріальних, фінансових і трудових ресурсів у секторах стратегічних агропродовольчих ринків, досягнення високого рівня продовольчої безпеки країни в умовах глобалізаційних викликів, забезпечення приросту податкових надходжень і соціальних відрахувань. Слід підкреслити, що трансформація інтеграційної політики із пасивної форми в активну передбачає реалізацію пріоритету економічних інтересів держави, як носія інтересів суспільства, а не суб' єктів, наділених ринковою владою.

Вищевикладене дає змогу запропонувати такі основні пріоритетні напрямки державного регулювання ІП на агропродовольчих ринках України:

- посилення контролю за діяльністю агрохолдингів в Україні шляхом впровадження комплексу заходів, як-то [5, с. 76]: виключити агрохолдинги із програм державної підтримки сільського господарства, позбавити їх податкових пільг, зобов'язати впровадити науково обгрунтовані сівозміни $з$ виробництвом трудомістких видів культур, запровадити спеціальний податок для агрохолдингів в розмірі $1 \%$ від вартості землі, що знаходиться в їх використанні, як соціальний податок для розвитку сільських територій;

- правова регламентація діяльності інтегрованих структур, розробка науково обгрунтованих нормативних рекомендацій, що враховують ринкові закони і різноманіття форм власності;

- реалізація виваженої антимонопольної політики 3 метою недопущення створення монопольних або олігопольних об'єднань, які обмежують вільну конкуренцію між економічними суб' єктами;

- вдосконалення механізму оподаткування шляхом раціонального поєднання фіскальної та стимулюючої функцій з метою управління сучасними IП $з$ позицій пріоритетності економічних інтересів держави та суспільства;

- фінансово-кредитне регулювання у вигляді фінансування державних програм розвитку стратегічних агропродовольчих ринків, субсидування елітного насінництва й племінної справи, компенсації частини витрат на придбання сільськогосподарської техніки, мінеральних добрив, хімічних засобів захисту рослин, страхування врожаю культур тощо;

- підтримка та стимулювання розвитку мережі сільськогосподарських кооперативів в УкраїHi.

Перелічені напрями державного регулювання ІП реалізуються через механізми, які повинні враховувати особливості та деформації відтворювальних процесів певних товарних ринків. Так, на ринку молочної продукції, з огляду на невирішені проблеми із якісним сировинним забезпеченням, для молокопереробних підприємств найбільш прийнятною формою гармонізації взаємовідносин із виробниками молока $є$ класична вертикальна інтеграція на основі створення власних молочних ферм та квазіінтеграція, основою якої $є$ укладання довгострокових розширених контрактів із агропідприємствами або молочарськими кооперативами. Вдосконалення інфраструктурного забезпечення ринку молочної продукції передбачає застосування механізмів державної підтримки створення регіональних мереж, заготівельно-збутових кооперативів, обладнання їх сучасними пунктами приймання й зберігання молока для його подальшої переробки, розробку й впровадження програми підвищення якості вітчизняної молочної продукції [10, c. 11].

На зерновому ринку, з огляду на залежність первинних зерновиробників від цінової політики трейдерів і тарифної політики приватних елеваторів, головним механізмом регулювання ІП $є$ державна підтримка створення мережі зернових обслуговуючих кооперативів, базовою ланкою яких є кооперативні елеватори. Головними завданнями таких кооперативів $\epsilon$ підвищення доходності безпосередніх виробників зерна, забезпечення для них (у т.ч. господарствам населення) доступності державної підтримки, узгодження попиту і пропозиції зерна із заданими параметрами якості, підвищення якості культур шляхом їх доробки та зберігання на кооперативному елеваторі [12, с. 312]. 
Розвинені країни використовують два головних механізми регулювання ІП: (1) підтримка формування рівноцінних 3 іншими секторами умов відтворення в усіх аграрних господарствах, незалежно від розмірів; (2) сприяння об'єднанню фермерів на некомерційних засадах як для організації спільного виробництва, так і для просування продукції на ринок. Некомерційні виробничі фермерські об'єднання (партнерства i S-корпорації в США і Австралії; GAEC i EARL у Франції; кооперативи колективного обробітку землі в Італії або Іспанії) дають можливість фермерам сформувати спільно оброблювані земельні ділянки, на яких можна використовувати високопродуктивну техніку і впроваджувати новітні технології. А фермерські збутові кооперативи та їх союзи можуть виставити на національному або міжнародному ринку будь-яку партію продукції своїх членів, забезпечивши їй як цінову, так і якісну конкурентоспроможність [6].

Так, у Франції через кооперативи фермери реалізують до $70 \%$ зерна, в Німеччині - близько $55 \%$. У багатьох розвинутих країнах кооперативи здійснюють переробку майже всього товарного молока. Так, у Данії ця частка складає 90 \%, стільки ж відсотків масла і сиру кооперативи постачають на експорт. У країнах Скандинавії і Фінляндії вони беруть найбільшу участь у переробці м'яса та молока: на них припадає 80 \% реалізації цієї продукції. У Нідерландах кооперативи реалізують понад $80 \%$ товарного молока, майже всі овочі, $95 \%$ фруктів і $90 \%$ вовни [15].

У 2013 р. в Україні діяло 562 сільськогосподарських обслуговуючих кооперативів, 3 них 26 $(4,6 \%)$ - зернових, 181 (32,2\%) - молочарських [15, c. 11]. Розвиток кооперативних структур на вітчизняних агропродовольчих ринках стримує невирішеність проблем оподаткування, зокрема визнання їх неприбуткового статусу, та недостатність державної підтримки створення нових і розвитку діючих кооперативів.
Висновки та перспективи подальших досліджень. У ході дослідження авторами досліджено природу економічної інтеграції як процесу, що підсилює механізми активізації товарно-фінансових потоків між секторами агропродовольчих ринків 3 метою забезпечення їх ефективного функціонування. Виділено дві форми інтеграції (активну та пасивну), за результатами аналізу сучасних ІП доведено домінування пасивної інтеграційної політики в аграрному секторі України. Використовуючи методику секторного аналізу відтворювальних процесів, визначено рушійні сили IП на стратегічних ринках зерна та молочної продукції, обгрунтовано головні напрями державної інтеграційної політики на даних ринках. Запропоновано розглядати державне регулювання інтеграційних процесів як взаємоузгоджений комплекс заходів, здійснюваних державою для досягнення стійких економічних, виробничих і технологічних зв'язків між суб'єктами і секторами товарних ринків, найповнішої реалізації їх відтворювальних функцій у макроекономічній системі. За результатами дослідження обгрунтовано пріоритетні напрями державного регулювання ІП стратегічних агропродовольчих ринків, зокрема: посилення контролю за діяльністю агрохолдингів, реалізація виваженої антимонопольної політики, вдосконалення податкового та фінансовокредитного механізмів, підтримка створення і розвитку сільськогосподарських кооперативів на базі світового передового досвіду.

Прикладне значення авторських розробок визначається можливістю їх використання державними органами влади в ході розробки інтеграційної політики як невід'ємної складової державної соціальноекономічної політики. Перспективи подальших досліджень полягають в обгрунтуванні пріоритетних напрямів і механізмів регулювання ІП на стратегічних аграрних і продовольчих ринках країни з урахуванням специфіки їх відтворювальних процесів.

\section{Література}

1. Економічна енциклопедія: У трьох томах. Т.3. /Ред. кол.: Мочерний С. В. (відп. ред.) та ін. - К.: Вид. Центр «Академія», 2002. - 952 с.

2. Лисюк В. М. Теоретико сутнісний аналіз економічної інтеграції як економічного процесу // В. М. Лисюк, Т. В. Деркач / Економічні інновації. - 2015. - №59. - С. 194-201.

3. Поляруш М. О. Агропромислова інтеграція - один із факторів системного розвитку АПК регіону // М. О. Поляруш, І. М. Поляруш, Н. А. Славіна / Збірник наукових праць ПДАТУ. - 2007. - №15. - С. $187-189$.

4. Мостовий Г. І. Агробізнес: державне регулювання: [монографія]. - Х. : Основа, 2002. - 299 с.

5. Зализко В. Д. Влияние агрохолдинизации сельскохозяйственных предприятий на социальноэкономическое развитие сельских территорий / В. Д. Зализко // Экономика Украины. - 2013. - № 6. - С. 71-77.

6. Осташко Т. О. Аграрний сектор: час принципово змінити орієнтири розвитку / Т. О. Осташко, Б. Й. Пасхавер та ін. // Дзеркало тижня. - 2010.- № 26. - С. 10-11.

7. Лысюк В. М. Воспроизводственная функция товарных рынков [монография] / В. М. Лысюк. - Одесса : ИПРЭЭИ НАН Украины, 2011. - 225 с.

8. Статистичний щорічник України за 2013 рік / За ред. О. Г. Осауленка. - К. : ТОВ «Август Трейд», 2014. - 533 c.

9. Основні економічні показники виробництва продукції сільського господарства в сільськогосподарських підприємствах за 2013 рік : Статистичний бюлетень / Відп. за випуск О. М. Прокопенко. - К. : Державна служба статистики України, 2014. - 88 с. 
10. Чмут А. В. Методологія секторного аналізу продовольчого ринку (на прикладі ринку молока і молочної продукції) / В. М. Лисюк, А. В. Чмут, Н. Л. Шлафман // Агроінком. - 2012.- № 4-6. - С. 6-11.

11. Chmut A. (2013) "The state and development trends manufacture of milk and dairy production by enterprise of Ukraine", Nauka i Studia, 9 (77), 19 - 23.

12. Нікішина О. В. Механізми регулювання інтегрованого зернового ринку: [монографія] / О. В. Нікішина. - Одеса: ІПРЕЕД НАН України, 2014. - 450 с.

13. Nikishina O. V. (2014) "Sectoral Analysis of Reproduction Processes at the Integrated Grain Market of Ukraine”, Nauka i Studia, 1 (111), 105 - 111.

14. Bondarchuk V, Alkoley J. R. (2015) "Cooperation as a way life", available at: http://www.zerno.org.ua/articles/coop/279 (Accessed Juli 09, 2015)

15. Шебанін В. С. Розвиток кооперації в АПК: проблеми та напрями їі подолання / В. С. Шебанін // Економіка АПК. - 2013. - № 2. - С. 9-12.

Стаття надійшала 15.07.2015

\author{
Павлов А.И. \\ доктор экономических наук, профессор, \\ заведующий кафедрой экономики промышленности, \\ Одесская национальная академия пищевых технологий \\ ул. Канатная, 112, г. Одесса, Украина, 65039 \\ E-mail: pavlovodessa@mail.ru \\ Лысюк В.M. \\ доктор экономических наук, профрессор, \\ заведующий отделом рыночных механизмов и структур \\ E-mail: vlisyuk@ukr.net \\ Деркач T.B. \\ кандидат географических наук, докторант \\ отдел рыночных механизмов и структур \\ Институт проблем рынка и экономико-экологических исследований НАН Украины \\ Французский бульвар, 29, г. Одесса, Украина, 65044 \\ E-mail: igd62@mail.ru
}

\title{
ГОСУДАРСТВЕННОЕ РЕГУЛИРОВАНИЕ ИНТЕГРАЦИОННЫХ ПРОЦЕССОВ НА СТРАТЕГИЧЕСКИХ АГРОПРОДОВОЛЬСТВЕННЫХ PЫHKAX
}

\footnotetext{
Экономическая интеграция является процессом, усиливающим механизмы активизации товарно-фринансовых потоков между секторами агропродовольственных рынков. В зависимости от степени реализации государственных экономических интересов, авторы выделяют две фрормы интеграции (интеграционной политики): активную и пассивную. Пассивная интеграционная политика реализуется под внешним давлением сильных субъектов или интеграционных структур, интересы которых не связаны с экономическими интересами государства. Активная интеграционная политика внедряется под влиянием государственной экономической политики, в которой интеграция выступает механизмом развития товарных рынков.

В Украине доминирует пассивная форма интеграции в агропродовольственной сфере, характерными признаками которой являются слабое влияние государства на интеграционные процессы, реализация экономических интересов агрохолдингов, что приводит к уничтожению социальных и экологических фрункций сельского хозяйства. Разработка и внедрение активной интеграционной политики обусловливает необходимость обоснования ее приоритетов на стратегических агропродовольственных рынках страны.

Используя методику секторного анализа воспроизводственных процессов, определены движущие силы интеграционных процессов на стратегических рынках молочной продукции и зерновых культур. В частности, на украинском рынке молочной продукции основными движущими силами углубления отношений субъектов на основе интеграции являются проблемы обеспечения сырьем молокоперерабатывающих предприятий, на зерновом рынке - проблемы сбыта и хранения культур первичными производителями, их зависимость от ценовой политики трейдеров, уменьшение производства продовольственного зерна и продуктов его переработки.
} 
На основании анализа доказано, что современные интеграционные системы не выполняют задачи преодоления диспаритета цен, обеспечения пропорционального распределения доходов между секторами агропродовольственных рынков, воспроизводственного уровня цен в базовом сырьевом секторе. Соответственно, возникает необходимость государственного регулирования интеграционных процессов, то есть внедрения комплекса мероприятий для достижения устойчивых экономических, производственных и технологических связей между субъектами и секторами товарных рынков, наиболее полной реализации их воспроизводственных функций в системе национальной экономики.

По результатам исследования обоснованы приоритетные направления государственного регулирования интеграционных процессов на стратегических агропродовольственных рынках Украины, а именно: (1) усиление государственного контроля за деятельностью агрохолдингов; (2) правовая регламентация деятельности интегрированных структур; (3) реализация взвешенной антимонопольной политики; (4) совершенствование механизмов налогообложения и финансово-кредитного регулирования; (5) поддержка развития сельскохозяйственных кооперативов.

Ключевые слова: интеграционные процессы, интеграционная политика, агропродовольственные рынки, воспроизводственные процессы, государственное регулирование.

\author{
Pavlov A.I. \\ Doctor of Economics, professor, \\ Head of Chair of Industrial Economics, \\ Odessa National Academy of Food Technologies \\ Kanatna, 112, Odessa, Ukraine, 65039 \\ E-mail: pavlovodessa@mail.ru \\ Lisyuk V.M. \\ Doctor of Economics, professor, \\ Head of department of market mechanisms and structures \\ E-mail:vlisyuk@ukr.net \\ Derkach T.V. \\ Ph.D. in Geography, Doctoral candidate \\ Department of market mechanisms and structures \\ Institute of market problems and economic \& ecological research \\ of National Academy of Sciences of Ukraine \\ Frantsuzskiy boulevard, 29, Odessa, Ukraine, 65044 \\ E-mail: igd62@mail.ru
}

\title{
STATE REGULATION OF INTEGRATION PROCESSES ON STRATEGIC AGROFOOD MARKETS
}

Economic integration is a process that enhances mechanisms of intensification commodity and financial flows between sectors of agrofood markets. Depending on degree of realization of state economic interests, authors identify two forms of integration (integration policy): active and passive. Passive integration policy is realized under external pressure strongest subjects or integration structures, whose interests are not related to economic interests state. Active integration policy implemented under the influence of state economic policy, in which integration is mechanism of commodity markets.

In Ukraine dominates passive form of integration into agri-food sector, characteristics of which is weak state influence on integration processes, implementation of economic interests of agricultural holdings, which leads to the destruction of social and environmental functions of agriculture. Development and implementation of active integration policy necessitates substantiation of its priorities on strategic agrofood markets of the country.

Using method sectoral analysis of reproduction processes, identified driving forces of integration processes on strategic markets dairy products and cereals. In particular, in Ukrainian market of dairy products the main driving forces of deepening relations on basis of integration is problem of raw milk processing plants, grain market - problems crop marketing and storage of primary producers, their dependence on pricing policies traders, reducing production of food grains and products its processing. 
Based on analysis proved that modern integration system do not perform task of overcoming the disparity in prices, ensuring proportional distribution of income between sectors agro-food markets, reproduction level of prices in basic raw materials sector. Accordingly, there is need for state regulation of integration processes, namely implementation of mutually agreed set of measures to achieve sustainable economic, industrial and technological links between actors and sectors of commodity markets, most complete implementation of reproduction functions in the system of national economy.

According to a study, substantiates the priority directions of state regulation of integration processes on strategic agrofood markets Ukraine, namely: (1) strengthening state control over activities of agricultural holdings; (2) legal regulation of integrated structures; (3) implementation of a balanced antimonopoly policy; (4) improving mechanisms of taxation and financial and credit regulation; (5) supporting development of agricultural cooperatives.

Keywords: integration processes, integration policy, agrofood markets, reproduction processes, state regulation.

\section{References}

1. Ekonomichna entsyklopediia: u trokh tomakh: T.3. (2002). Red. kol.: Mochernyi S. V. (vidp. red.) ta in., Kyiv: Vyd. Tsentr Akademiia, 952.

2. Lysiuk V. M., Derkach T. V. (2015). Teoretyko sutnisnyi analiz ekonomichnoi intehratsii yak ekonomichnoho protsesu, Ekonomichni innovatsii, 59, 194-201.

3. Poliarush M. O., Poliarush I. M., Slavina N. A. (2007). Ahropromyslova intehratsiia - odyn iz faktoriv systemnoho rozvytku APK rehionu, Zbirnyk naukovykh prats PDATU, 15, 187-189.

4. Mostovyi H. I. (2002). Ahrobiznes: derzhavne rehuliuvannia: [monohrafiia]. - Kharkiv: Osnova, 299.

5. Zalizko V. D. (2013). Vliyanie agroholdinizatsii selskohozyaystvennyih predpriyatiy na sotsialnoekonomicheskoe razvitie selskih territoriy, Ekonomika Ukrainyi, 6, 71-77.

6. Ostashko T. O., Paskhaver B. Y. ta in (2010). Ahrarnyi sektor: chas pryntsypovo zminyty oriientyry rozvytku, Dzerkalo tyzhnia, 26, 10-11.

7. Lyisyuk V. M. (2011). Vosproizvodstvennaya funktsiya tovarnyih ryinkov [monografiya], Odessa: IPREEI NAN Ukrainyi, 225.

8. Statystychnyi shchorichnyk Ukrainy za 2013 rik (2014), za red. O. H. Osaulenka, K.: TOV «Avhust Treid», 533.

9. Osnovni ekonomichni pokaznyky vyrobnytstva produktsii silskoho hospodarstva v silskohospodarskykh pidpryiemstvakh za 2013 rik: Statystychnyi biuleten (2014). Vidp. za vypusk O. M. Prokopenko, K.: Derzhavna sluzhba statystyky Ukrainy, 88.

10. Lysiuk V. M., Chmut A. V., Shlafman N. L. (2012). Metodolohiia sektornoho analizu prodovolchoho rynku (na prykladi rynku moloka i molochnoi produktsii), Ahroinkom, 4-6, 6-11.

11. Chmut A. V (2013). The state and development trends manufacture of milk and dairy production by enterprise of Ukraine, Nauka i Studia, 9 (77), 19 - 23.

12. Nikishyna O. V. (2014). Mekhanizmy rehuliuvannia intehrovanoho zernovoho rynku, Odesa: IPREED NAN Ukrainy, 450.

13. Nikishina O. V. (2014). Sectoral Analysis of Reproduction Processes at the Integrated Grain Market of Ukraine, Nauka i Studia, 1 (111), 105 - 111.

14. Bondarchuk V, Alkoley J. R. (2015). Cooperation as a way life, available at: http://www.zerno.org.ua/articles/coop/279 (Accessed Juli 09, 2015).

15. Shebanin V. S. (2013). Rozvytok kooperatsii v APK: problemy ta napriamy yii podolannia, Ekonomika APK, 2, 9-12. 